\title{
The emerging knowledge economy: an analysis of the issues and possible outcomes of the information age in the context of a Central Eastern European creative city
}

The process of the transformation to the new, turbulent, ambiguous economy has been widely recognized both by academics and executives. In contrast to the industrial era, the new environment demands a diversified range of adjustments in many aspects of business and academic practice. A new set of assumptions is needed in order to understand and operate in the new systemic conditions, not only for individuals, but also business organizations and institutions. Sustaining a competitive advantage is increasingly dependable on the understanding of the basic processes and functions of the industries. Thus, without understanding the wide economic context it is not possible to compete or navigate in it.

This paper analyses the issue of the creative city and sets it in the context of the recent Central Eastern European environmental changes. It focuses on the exemplary metropolitan area of Cracow and gives a brief introduction to the collective visions of its future. The paper uses three approaches to the vision of the agglomeration's future: (1) High culture (2) Low-cost tourism and (3) Business and education, as well as tries to offer a proposition both bridging them and developing further the urban and promotional strategy.

The main part of the paper justifies the proposed solution by identifying both regional and global economic situation as the main causes that necessitate a change in the approach to the agglomerations' future.

The analysis conducted below is based on the notions grounded in the social sciences. One of them, crucial to understand the line of reasoning in this paper, is 'collective vision of the future' or 'social future'. Basing on the concept of the 'collective memory' created by Halbwachs (1969), I have decided to formulate the notion referring to the socially determined attitude towards the future. My perspective proposes to tackle it, basing on the collective approach, qualitatively different from the individual perspective. Purposefully, I have decided to propose a new notion, much 'softer' in comparison to Marx's 'ideology', as the ideologisation rather influences the 'collective vision of the future' than replaces it.

\section{THE NEW ECONOMIC ERA}

Recent environmental changes are being widely analysed in the literature. Numerous scholars and business analysts call our times the new economic period due to the radical reforms and changes in the economic environment (e.g. Carlaw et al. 2006). Although the 
notion and the level of the process is rather vague and disputable, for the purpose of this work it is justified to call it the 'transition to the knowledge economy' and to follow the notions formulated in the process of analysis under various operational names, such as 'knowledgebased economy', 'knowledge-driven economy', 'new economy', innovation-based economy', 'learning economy', 'digital economy', 'network economy', 'global economy' or 'border economy'. The work aims neither to measure the transition nor to assess it, it focuses rather on the features of the new period, its demands and possible outcomes. The main interest is in its influence on the collective vision of the future of Cracow agglomeration and its approach towards it.

To start the discussion, the phenomenon of the ongoing transition has to be defined. Among many academic propositions, Powell et al. note that the main feature of the knowledge-based economy is 'production and services based on knowledge-intensive activities that contribute to an accelerated pace of technical and scientific advance, as well as rapid obsolescence with a greater reliance on intellectual capabilities than on physical inputs or natural resources' (Powell et al. 2004:199).

The phenomenon is widely recognized by numerous institutions. OECD, the European Union and the non-governmental organisations recognise the phenomenon and formulate their own operational definitions in order to change and influence the new conditions. More often, they indicate that survival in the knowledge economy strongly depends on the ability to recognise the turbulent and ambiguous conditions and in effect to take part in and adapt to them, mainly by combining the theoretical frameworks with the current pragmatic needs, ${ }^{1}$ or on the ability to recognise the threats and 'to bring a spirit of enterprise to life as an employee and a citizen in terms of developing a capacity for creativity, innovation, flexibility and intellectual curiosity' (Commission of the European Communities 2002) (European Round Table of Industrialists 2001). The turbulence, ambiguity, global competition, knowledge workers shortage, creative class demand, oversupply of and easy access to information are exemplary classical symptoms of the new economy which is strongly present in all possible aspects of workplace and social life. The knowledge-based economy reshapes even the managerial practices, the nature of the worker's jobs or the design of the office space and the industrial estates (Seetharaman et al. 2002, Murray et al. 2007, Harrison 2002). It demands new paradigms and countless adjustments. According to Harrison, none of the factors should be omitted as the new economy makes a revolutionary change of the world. Additionally, the issue is increasingly important as all the aspects mentioned above do not occur in the wider context in the 'traditional' production economy, which is often placed on the other pole when compared to the knowledge-based model. Although both notions can be interpreted as Weberian ideal types, they are a useful tool for the research and create a framework for mapping the recent economic developments. Due to the limited space of this paper, these issues are not extendedly presented, however, they strongly correlate with the main topic - the Polish transition, both to the market and knowledge economy, and the impact on the social element of the process.

\section{Central Eastern Europe - the past and the future}

Central Eastern European transition to the knowledge economy is on a different track, comparing to the most developed and richest countries. Mainly because of the historic past,

\footnotetext{
${ }^{1}$ e.g. 'Learning Society' - 'Education and Skills or Korea and the Knowledge-Based Economy'
} 
its liberal free market economy has developed much later comparing to the Western World. Years of socialist yoke influenced all the social aspects: from flattering of the social structure and destroying the private business ownership to changing the role of the church and launching one of the biggest trade union movements in the world. Almost twenty years from the Polish institutional shift, and thirty years from the early signs of 'state' capitalism such as opening the market to the free initiative and emerging traces of the elements of the free economic system, Poland is trying to catch up with the economies that three decades ago were still labelled in the Soviet Block the menace for the peace (Sztaniskis 1994). Although Polish collective past is widely discussed and very emotional, still causing thrill in the public sphere, the national economy seems to develop at a regular pace, without any concern about it. The macroeconomic indicators prove that the political stability, EU accession, cheap labour cost and proximity to the potential export markets can be a sufficient stimulus for foreign direct investment and regional economic development. The Polish society is moderately polarised, and Poland can be labelled a democratic and, to a certain degree, developed country. Moreover, the Polish transition has never been really based on 'the fall' of the previous economic system. This spectrum of features entitles us to claim that the Polish transition has been a form of transition to the market economy.

Additionally, some other processes can be found in it. As Gumula puts it: 'we are wearing the distorted systemic garment, when the West is showing off the new, still incomplete pieces of clothing, often called globalisation or post-modernity' (Gumula 2008:302). I elaborate Gumula's statement by assuming that the transition has launched a series of transformations in various social aspects. One of them was pushing the national Polish economy towards the global knowledge-based model. In other words, surprisingly, the side-effect challenge of the liberal market transition was to cope with the early stages of the transition to the knowledge economy. Thus, as the processes advance, the new needs emerge. For instance, after the systemic change, the business and political elites had to be recruited and educated. Nowadays, the new demands emerge as the global economic system changes and the Polish society faces the sets of still-unsolved problems, as the issue of privatisation or state interventionism, and the new requirements and needs connected with the transition to the knowledge-based model.

\section{The COllective Vision OF THE FUtURE - THE CASE OF CRACOW}

The Cracow metropolitan area places the agglomeration among the biggest and most important links of the Polish economy. I have decided to select this location basing on the undoubted potential of the agglomeration. Moreover, the phenomena I speculate about are viably visible in the cultural and political life of the city. Lastly, the agglomeration at the moment remains a very important and strong economic and cultural link within the country and in the Poles' national identity.

The macroeconomic and statistic indicators prove that the region of the agglomeration and the Malopolskie Voivodship belong to the potentially and strategically most important ones in Poland. The relatively big area, covering almost 5\% of the country's territory, combined with the high emission of industrial air pollutants (9\% in Poland), almost 7\% of Polish urban population, $8,1 \%$ of Poles employed, low unemployment rate ( $12 \%$ in 2007$), 7,3 \%$ of 
the Polish GDP creation and an increasing number of university graduates give a bright image of the city that presents an immense potential in order to be an important economic link in the Polish transition to the knowledge economy (Statistical Office in Krakow 2007).

For the purpose of this work I have decided to analyse the current influences on the social perception of Cracow's future. My analysis concentrates on the process of dealing with an uncertain and emergent environment connected to the transition to the knowledge economy. Basing on the assumption discussed above, I have created a typology that places all the forms and visions of the collective future on one axis and presents the possible points of osculation. All the three approaches presented here are interconnected and aim to present the process of establishing the social vision of strategic response to the environmental changes and prospective redefinition of the urban identity.

The three visions or 'ideological symptoms': 'high-culture', 'low-cost tourism' and 'business \& education' often oppose each other and correlate. The projects of any architectonic or urban intervention launch a snowball discussion that usually takes many years as the collective future is not agreed. The nature of the pluralism or any of the approaches should not be assessed in this place. What is more important and interesting from the perspective of this paper are the reasons for such a situation, absence of compromise and meritocratic discussion.

My interpretation of such a division is that, due to the deficiency in explicit exposition of any plan, vision or strategic undertakings, the interest groups are losing the track of the area development direction. Moreover, the changes caused by the post-socialist heritage, combined with the new economic conditions, the emerging turbulence and demands for global sets of nodes erode 'traditional' social life and demand a new set of abilities in order to navigate in such an environment.

In such conditions policy-makers and interest groups try to influence the collective vision of the future, according to the three approaches. For the purpose of this work I have decided to use a term analogical to the collective memory mainly due to the social impact on the collective vision. In other words, I assume that just as social actors influence the image of the social past, using various tools such as ideologies, reference to the history, identity or collective events, there also exists the notion of the collective vision of the future, which theoretically is based on the same assumptions and vector, but differs by reference to the opposing time direction. Both influenced and demanded for the stakeholders' purposes are the very crucial element in the agglomeration's social life in most of its aspects.

My theoretical proposition of the response to the observed attitudes is based on the theory formulated by authors such as Florida, Landry and Anderson and Ray. (Florida 2002, Landry 2000, Anderson et al. 2001) The authors' main assumptions are that the 'creative city' can be an economic, social and cultural stimulator of the development of the region. I develop their proposition further, formulating the 'creative strategy' that can soften the process of the transition to the knowledge economy and, in effect, help the agglomeration adjust to te market economy, specifically in the Polish case.

The concept of the creative city is based on the notion of a creative class. Florida identifies the creative sector as the most dynamic and influential sector of the new economy (Florida 2002). The indicators, from e.g. British DCMS, proof that the creative class can be identified as the potential conductors of change due to its mobility and entrepreneurship (Richards 2005). 


\section{THE JUSTIFYING OUTCOMES}

Mendieta or Hall try to answer the first set of questions by focusing on the quality of the agglomeration. Both the authors claim that it should attract the members of the creative class and knowledge workers to select the location and, at the same time, offer a spectrum of potential entertainment and attractive places that can be (but do not necessarily have to be) consumed by them (Mendieta 2001, Hall 1998). Quoting Hospers: 'the knowledge-based economy is based on possibility. The bigger number of possibilities the city offers, the more attractive name it gets' (Hospers et al. 2005:10). At the same time Edvinsson claims that the creative class 'does not accept familiar patterns and duplicates, which the concept of the creative city seems to omit' (Edvinsson 2002:202).

Cracow, the agglomeration and its set of capabilities seems to be the most desired ground for the creative city development. The unique historic monuments (Main Market and Nowa Huta) and artistic (Kazimierz and Podgorze) districts combined with the number of potential creative class members, recruited from 23 higher education institutions, the considerable presence of the creative capital and relatively high quality of the city space can be identified as a potentially good place for concentrating the 'creative class'.

Placing the agglomeration in the wider context - such an approach could strongly influence the Polish transition to the knowledge economy. How? The possible impact of the creative class could have enormous consequences. Due to globalisation and recent technological and political changes the demand for its services and accomplishments has been higher than ever before. The creative class is becoming increasingly important, being one of the drivers of change in the knowledge economy, and it will be the basis for the future surfing on the edge of chaos that, according to Pascale (1999), could substitute the notion of the competitive advantage gaining in the knowledge-based economy context. As previously mentioned, the number of creative industries' participants increases. Poland, due to its geopolitical location, is not able to participate in price-based competition in the production industries with Southern Asian or Latin American countries. Probably strategic drifting towards high scale production-based economy will not be the most rational move.

Moreover, as we are facing the transition period, it demands a change in the reality perception. It is a form of Kuhnian scientific revolution - a new paradigm is needed. And applying the new paradigm requires time, consistency and resources. Thus, debating the ending moment of the old, production-based economy does not have any practical sense. However, an analysis and diagnosis of the new processes opens a vast range of possibilities and enables actors to prepare for their aftermath. Thus, due to its theoretical framework, the concept of a creative city can be criticised, for instance for its authors' controversial research methodology, but it opens a perspective for a new process, important to the general social, cultural and economic development.

The implementation of the creative city strategy requires a highly skilled, resourceful and consistent approach, mainly of the decision makers and planners. Its effect, however, can impact all the social groups within the agglomeration. The new proposition can affect Cracow in both economic and social dimensions.

Firstly, it can enable the general economic development at both regional and national level. The creative city can stimulate the creativity level among employees and business organisations, boosting their competitiveness on the market. This can cause the increasing 
prestige, connected with consistent marketing campaigns, unique social space formation or highly promoted unique historic tradition, which can be the first step to attract both tourists and foreign direct investment. Cracow, as the creative city among other Polish agglomerations, can be identified as the potential leader of the development towards the knowledge economy. Moreover, Central Eastern Europe is lacking creative cities. None of the countries participates in the UNESCO's Creative Cities Network, although some major centres have the potential (UNESCO 2008).

Secondly, the creative city can influence social aspects of the metropolitan area. Firstly, a very explicit form of reforming the urban social space and cultural strategy can definitely help to look for the inhabitants' identity. However, this does not mean that unitarism should be pursued, it means rather that the collective vision of the future should be debated and settled. This opens a discussion of the political nature - how much of each approach presented above will have its part in establishing it. Quite surprisingly, consistency in the realisation of the vision is more important than an answer to that question. Moreover, the process of discussing the collective vision should take its time and adjust to the needs of the agglomeration. However, the main core - the creative city concept - should remain unchanged.

The creative city does not impose any radical solutions. Basing on the experience of such cities as Barcelona or Berlin, Cracow can regulate its socioeconomic issues using the creative city strategy. Regulating the social space and creating a kind of 'business' or 'historic zones' (whose elementary forms exist in most of the cities) can help planners and architects regulate the urban life and improve the procedures. Lacks in physical management plans, or long queues for construction permits are the most disruptive and problematic issues of Cracow and dozens of major Polish agglomerations. Speculatively, a creative city strategy could be a motivator to regulate the issues of such a nature. Such a regulation can open a different collective vision of future intercessors to other perspectives and help building the general, regional and plural identity of Cracow.

\section{Conclusions}

The Polish economy remains one of the most promising and changing economies in Europe. Its attractiveness, caused by geopolitical location, human and natural potential, world famous history and transition processes, creates a unique set of features that attract both foreign investment and regional investors. Facing the last environmental changes, mainly connected with the processes of the transition to the market and knowledge-based economy, it still develops and changes.

In Poland there exists a set of major economic organisms that changes the country and creates most of its GDP. The metropolitan areas, including the example of Cracow, discussed above, are stimulators and attractors of both human and economic development. The open question that remains unsolved is how the metropolitan areas can improve their keystone performance. Some of the propositions of such improvements are the creative city strategies that have numerous possible outcomes. Most of the outcomes previously analysed in the literature are of economic nature. The conclusion I draw is that the creative city strategy has an enabling force - it asks the questions about the citizens' identity and seeks for answers in all social aspects of the metropolitan life. Finally, it strongly influences the collective vision 
of the agglomeration's future that, in this case, might be the most crucial element of the final results of the strategy.

\title{
Literature
}

Anderson, S., Ray, P., 2001, The Cultural Creativities: How 50 million People are Changing the World, New York.

Carlaw, K., Oxley, L., Walker, P., Thorns, D., Nuth, M., 2006, Beyond the Hype: Intellectual Property and the Knowledge Society / Knowledge Economy in "Journal of Economic Surveys", Vol. 20, Issue 4.

Commission of the European Communities, 2002, Towards a Research Area in "Communication from the Commission to the Council, the European Parliament, the Economic and Social Committee and the Committee of the Regions", accessed online: http://ec.europa.eu/research/era/pdf/com2000-6-en.pdf (02.11.2008).

Edvinsson, L., 2002, Corporate Longitude, Harlow.

Florida, R., 2002, The Rise of the Creative Class: And How It's Transforming Work, Leisure, Community and Everyday Life, New York.

Gumula, W., 2008, Teoria osobliwości spolecznych. Zaskakujaca transformacja w Polsce, Warszawa

Halbwachs, M., 1969, Społeczne ramy pamięci, Warszawa.

Hall, P., 1998, Cities in Civilization, New York.

Harrison, C., 2002, Accommodating the New Economy: The SANE Space Environment Model, "Journal of Corporate Real Estate": Vol. 4 Issue 3.

Hospers, G., van Dalm, R., 2005, How to Create a Creative City? The Viewpoints of Richard Florida and Jane Jacobs in: "Foresight", Vol. 7, Issue 4.

Landry, C., 2000, The Creative City: A Toolkit for Urban Innovators, Strout.

Mendieta, E., 2001, Invisible Cities: a Phenomenology of Globalization from below, "City", Vol. 5, Issue 1.

Murray, A., Greenes K., 2007, From the Knowledge Worker to the Knowledge Economy, "The Journal of Information and Knowledge Management Systems", Vol. 37, Issue 1.

Pascale, R., 1999, Surfing the Edge of Chaos, "Sloan Management Review", Spring.

Powell, W., Snellman, K., 2004, The Knowledge Economy, "Annual Review of Sociology", Vol. 30.

Richards, G., 2005, Development for the Creative Industries: the Role of Higher and Further Education Media and Sport, "Creative Industries Higher and Further Education Forum".

UNESCO, 2008, Towards Sustainable Strategies for Creative Tourism, CLT/CEI/CID/2008/RP/66.

Seetharaman, A., Bin Zaini Sooria, H.H., Saravanan, A.S., 2002, Intellectual Capital Accounting and Reporting in the Knowledge Economy, "Journal of Intellectual Capital", 3(2).

Staniszkis, J., 1994, Dylematy okresu przejściowego. Przypadek Polski, [in:] Zmierzch socjalizmu państwowego. Szkice z socjologii ekonomicznej, Warszawa.

Statistical Office in Krakow, 2007, Statistical Yearbook, Krakow.

\author{
Miłosz Miszczyński \\ Uniwersytet Jagielloński, Kraków \\ e-mail: milosz.miszczynski@uj.edu.pl
}

